\title{
Use of lipids to study the trophic ecology of deep-sea xenophyophores
}

\author{
J. Laureillard ${ }^{1, *}$, L. Méjanelle ${ }^{1}$, M. Sibuet ${ }^{2}$ \\ ${ }^{1}$ Laboratoire de Biogéochimie et Chimie Marines, Case 134, tours 24-25, IPSL, Université Pierre et Marie Curie, \\ 4, Place Jussieu, 75005 Paris, France \\ ${ }^{2}$ Département Environnement Profond, IFREMER Centre de Brest, BP 70, 29280 Plouzané, France
}

\begin{abstract}
Xenophyophores, widespread giant deep-sea protists, dominate the megafaunal organisms visible on the seafloor in some areas. Owing to the extreme fragility of their tests (external part), little is known about them, and their diet is largely a matter of speculation. The extensive accumulation of fecal pellets (stercomes) within their tests attests to the degree to which xenophyophores feed on particulate matter. During the EUMELI 2 cruise, xenophyophores were recovered intact at the surface of box-cores from an abyssal mesotrophic site in the northeastern Atlantic. They were identified as Syringammina corbicula. In our study, we compare the lipid composition of xenophyophores collected at the top of cores with sediment from the same mesotrophic environment devoid of these protists. The distribution of lipid classes was obtained by the use of the Iatroscan (TLC-FID) technique, and the molecular composition of several lipid classes containing fatty acids and sterols was investigated. Of special interest are the triacylglycerols of xenophyophores, energy storage lipids in animals, resulting in part from fatty acids found in their diet. They contained a higher level of bacterial fatty acids than those in the reference sediment. It would seem that, in addition to particle trapping, xenophyophores also feed on microbes. Our study points to the occurrence of a specialized bacterial flora, probably growing on the stercomes, which might serve as a secondary food source different from the microflora found in the control sediment.
\end{abstract}

KEY WORDS: Xenophyophores · Lipids · Nutrition · Deep-sea · Northeastern tropical Atlantic

\section{INTRODUCTION}

On the deep-sea floor, tests of agglutinating xenophyophores are often the dominating biogenic structure present at bathyal and abyssal depths below $500 \mathrm{~m}$. They range from a few millimeters to $25 \mathrm{~cm}$ in length. Xenophyophores (rhizopod protozoans) were recently recognized as belonging to the foraminifera group (Pawlowski et al. 2002). An extensive accumulation of waste pellets (stercomes), packed together in strings covered by a thin organic membrane, is contained inside the tubes of the agglutinated test composed of foreign particles. The protoplasm of xenophyphores is a multinucleate plasmodium enclosed as strands within a branching organic tube. Many of the descriptions and theories on xenophyophores were initiated by the pioneering works of Tendal (Tendal
1972, 1979, 1994, 1996, Tendal \& Gooday 1981, Tendal et al. 1982).

Despite the presumed ecological importance of these agglutinated xenophyophores in bathyal and abyssal environments, little information is available regarding their growth (Gooday et al. 1993), their life cycle, and their nutrition habits, and they are not available in cultures. Initially, xenophyophores were described as suspension feeders (Tendal 1972) or surface-deposit feeders. Traces of pseudopode movements on surface sediments indicate that they feed by active uptake (Gooday et al. 1993). In addition, their reticulated tests act as elaborate particle traps, often oriented parallel to the flow, the shapes and sizes of reticulations inducing a further entrainment of water, in order to enhance the deposition of particles (Levin \& Thomas 1988). Xenophyophores generally thrive in regions where the flux 


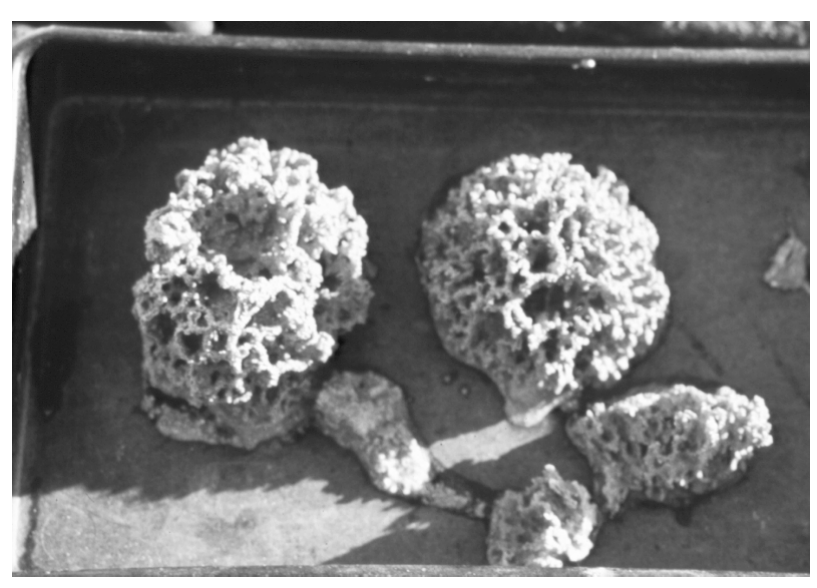

Fig. 1. Syringammina corbicula (6 $\mathrm{cm}$ in diameter) on the Cape Verde Plateau

of nutritive particles is high. Similar to other benthic foraminifera (Gooday 1996, Levin et al. 1999), xenophyophores can rapidly process fresh organic matter from seasonal inputs of phytodetritus, well documented in the northeastern Atlantic (Billett et al. 1983, Méjanelle et al. 1995). Xenophyophores are presumed to consume sedimentary particles by extracellular digestion in lacunae, which leads to an accumulation of stercomes (Tendal 1979), or by the direct absorption of dissolved organic matter (Sibuet 1991, Levin \& Gooday 1992, Riemann et al. 1993).

Compared with those from the Pacific, xenophyophore tests from the North Atlantic seem to be particularly fragile (Tendal \& Gooday 1981, Gooday \& Tendal 1988, Gooday 1991, 1996). Though visible in bottom photographs taken during the sample collection, they are totally disrupted by conventional sampling methods (Tendal \& Gooday 1981, Gooday \& Tendal 1988, Gooday 1991). Therefore, these animals are easily overlooked or lost in the sampling process, in spite of their significant presence in the deep-sea. In the framework of the France-JGOFS programme, during the EUMELI 2 cruise, a large photographic survey was performed using the autonomous submersible Epaulard to observe the spatial distribution of the epibenthic fauna. At an abyssal mesotrophic site, a high density of xenophyophores was observed (ca. $3 \mathrm{~m}^{-2}$; Sibuet et al. 1993). A sole species was present: Syringammina sp. (Cosson et al. 1997), described in Tendal (1972) and Gooday (1996) (Fig. 1). In addition, Richardson (2001) collected xenophyophores at the same site, Cape Verde Plateau (18 $\left.28^{\prime} \mathrm{N}, 21^{\circ} 02^{\prime} \mathrm{W}\right)$, and identified them as Syringammina corbicula.

Until now, the lipid characterization of xenophyophores has not been undertaken, but recently that of an agglutinated foraminiferan Bathysiphon capillare was published (Gooday et al. 2002). During the
EUMELI 2 cruise, a limited number of intact individuals were recovered, which gave us the opportunity to study their lipids. The lipid composition of Syringammina corbicula was compared with that of surficial sediments from the same environment, but devoid of these protists, in order to gain more information on these poorly understood protozoans. Various lipid classes are present in animals. Triacylglycerols (TAG) and wax esters (WE) are storage lipids whose constituent fatty acids partly originate from their diet. Consequently, fatty acid composition of these lipid classes provides information on the diet of xenophyophores. Additionally, phospholipids (important constituents of membranes) contain the fatty acid biomarkers for living organisms and can give an insight into specific biomarkers of the study animals.

\section{MATERIALS AND METHODS}

Sampling site and sample processing. The EUMELI JGOFS programme sampled 3 sites of contrasting trophic regimes: eutrophic (EU), mesotrophic (ME) and oligotrophic (LI) sites in the tropical northeastern Atlantic. Sediments at the 3 sites were collected during January and February 1991, using RV 'Atalante'. Xenophyophores were only found at the mesotrophic site $\left(18^{\circ} \mathrm{N}, 21^{\circ} \mathrm{W}\right)$. Intact animals were collected in 3 different box cores, using a modified $50 \times 50 \mathrm{~cm}$ USNEL box corer (Hessler \& Jumars 1974), equipped with large top-flaps to minimize the bow-wave effect. Xenophyophores were collected for lipid analyses at the surface of the box cores (Table 1) by sliding a stainless steel spatula underneath and combined for analysis. For comparison, a mesotrophic sediment free of xenophyophores was collected from a core at the same site (Table 1) using a SMBA multicorer (Barnett et al. 1984) with 12 tubes of $6 \mathrm{~cm}$ inner diameter that provided cores with an undisturbed sediment/water interface (Legeleux et al. 1994). For this study, the upper sediment ( 0 to $0.5 \mathrm{~cm}$ ) of the KTB6 core was chosen for analyses. On board, cores were immediately sliced and the samples were stored frozen at $-70^{\circ} \mathrm{C}$ until return to the laboratory. Then, xenophyophores and sediments

Table 1. Position of the samples analysed. Sed: reference sediment devoid of xenophyophores; xeno: xenophyophores

\begin{tabular}{|lcccc|}
\hline Sample & Core & Latitude & Longitude & Depth (m) \\
\hline Sed & KTB 6 & $18^{\circ} 31.96^{\prime} \mathrm{N}$ & $21^{\circ} 03.12^{\prime} \mathrm{W}$ & 3121 \\
Xeno & KGS 22 & $18^{\circ} 29.09^{\prime} \mathrm{N}$ & $21^{\circ} 03.18^{\prime} \mathrm{W}$ & 3112 \\
& KGS 29 & $18^{\circ} 34.06^{\prime} \mathrm{N}$ & $21^{\circ} 58.57^{\prime} \mathrm{W}$ & 3134 \\
& KGS 32 & $1^{\circ} 29.33^{\prime} \mathrm{N}$ & $21^{\circ} 05.33^{\prime} \mathrm{W}$ & 3080 \\
\hline
\end{tabular}


were freeze dried. Freeze drying destroyed the structure of the organisms, so that entire tests were treated as a whole. The 2 samples selected for analysis - combined xenophyophores and the upper sediment devoid of xenophyophores - were treated identically: homogenized by short-term grinding, stored under argon at $<20^{\circ} \mathrm{C}$ and analysed. Additional specimens of xenophyophores, collected at the same sites, were fixed in $5 \%$ formalin for microscopic observation. Unfortunately, it was impossibsle to perform any detailed cytological work because they were totally destroyed during transport.

Analysis of lipid classes. The analytical procedure used for the lipid extraction and analysis using a Iatroscan MK-5 analyser (thin layer chromatography/ flame ionization detector; TLC/FID) is described in detail by Laureillard et al. (1997) and Pinturier-Geiss et al. (2001).

Analysis of fatty acids and sterols. TLC: An aliquot of the total lipid extract was separated into 9 subfractions for molecular characterization of fatty acids of the different lipid classes using TLC. This was performed on $20 \times 20 \mathrm{~cm} 150$ A silica gel plates (Whatman). The plates were washed twice with methanol to eliminate impurities and dried in precombusted aluminium foil in a fume hood. Several mixtures of solvents were used as mobile phases to separate successive lipid classes according to their respective polarities (Table 2). Recoveries for lipid classes were ca. 80 to $90 \%$.

Derivatization and gas chromatography (GC) analysis: The lipid extracts were treated as described in Laureillard et al. (1997). Briefly, the acyl lipid classes were transesterified, after addition of an internal standard: deuterated tricosanoic acid $\left(\mathrm{C}_{22} \mathrm{D}_{45} \mathrm{COOH}\right)$. Fatty acid methyl esters (FAME) were prepared by transesterification in toluene with BF3/methanol $(1: 2, \mathrm{v} / \mathrm{v})$ at $65^{\circ} \mathrm{C}$ for $1 \mathrm{~h}$. For gas chromatographic analysis, the sterols were converted to their corresponding trimethylsilyl ether derivatives using a mixture of bis(trimethylsilyl)-trifluoroacetamide and trimethylchlorosilan (BSTFA-TMCS, 99:1, Silyl-99). $\alpha$-Cholestane was used as an internal standard for quantification. FAME were analysed using both a polar (BPX 70) and a non-polar column (HP5). GC analysis of sterols was carried out on a non-polar DB5 column. Structural assignments were based on comparison of the GC retention times with those of authentic standards, and by interpretation of mass spectra or comparison with published spectra. Monounsaturated fatty acid doublebond position was determined by gas chromatography - mass spectrometry (GC-MS) analysis of the dimethyl disulphide (DMDS) adducts.

Nomenclature: Fatty acids (FA) are designated, for example, as 22:6 63 , where 22 is the total number of carbon atoms, 6 is the number of double bonds and 3 is the position of the double bond nearest the methyl end. The sediment bearing xenophyophores is named 'xeno' and the reference sediment devoid of protists is named 'sed'.

\section{RESULTS}

\section{Bulk parameters}

Particulate organic carbon (POC), particulate organic nitrogen (PON), C/N (POC/PON ratio), and total free lipids ( $($ free lipids) for the xenophyophore sample (xeno) and the reference sediment (sed) are reported in Table 3. POC and $\Sigma$ free lipid values were significantly higher for the xeno sample: 6.6 and $0.78 \mathrm{mg} \mathrm{g}^{-1}$, respectively, compared with $4.1 \mathrm{mg} \mathrm{g}^{-1}$ and $0.22 \mathrm{mg} \mathrm{g}^{-1}$ in the control sediment. The $\mathrm{C} / \mathrm{N}$ values lay in a close range: 11.0 and 12.4 , respectively. The sed bulk parameters are in agreement with other results from sediments collected in the same mesotrophic site (Relexans et al. 1996). The PON and $\Sigma$ free lipids for the xeno

Table 2. Separation of lipid classes using thin layer chromatography (TLC)

\begin{tabular}{|c|c|c|c|}
\hline Mobile phase & Elution distance & Compounds & Eluent used for extraction from silica gel \\
\hline $\begin{array}{l}\text { Hexane-diethyl ether, } \\
95+5(\mathrm{v} / \mathrm{v})\end{array}$ & Upper side +10 min & Hydrocarbons & $10 \mathrm{ml}$ diethyl ether \\
\hline $\begin{array}{l}\text { Hexane-diethyl ether-acetic } \\
\text { acid } \\
75+25+1(\mathrm{v} / \mathrm{v}) \text { twice }\end{array}$ & $\begin{array}{l}3 \mathrm{~cm} \text { from the } \\
\text { upper side }\end{array}$ & $\begin{array}{l}\text { Wax esters } \\
\text { Triacylglycerols } \\
\text { Free fatty acids } \\
\text { Alcohols + sterols } \\
\text { Diacylglycerols } \\
\text { Monoacylglycerols }\end{array}$ & $\begin{array}{l}10 \mathrm{ml} \text { diethyl ether } \\
15 \mathrm{ml} \text { diethyl ether } \\
10 \mathrm{ml} \text { methylene chloride - methanol, } 50+50(\mathrm{v} / \mathrm{v})\end{array}$ \\
\hline $\begin{array}{l}\text { Ether-dimethylketone, } \\
50+50(\mathrm{v} / \mathrm{v})\end{array}$ & $\begin{array}{l}6 \mathrm{~cm} \text { from the lower } \\
\text { side }\end{array}$ & Glycolipids & $10 \mathrm{ml}$ methylene chloride-methanol, $50+50(\mathrm{v} / \mathrm{v})$ \\
\hline Methanol & $\begin{array}{l}4 \mathrm{~cm} \text { from the lower } \\
\text { side }\end{array}$ & Phospholipids & $\begin{array}{l}10 \mathrm{ml} \text { methylene chloride - methanol, } 50+50(\mathrm{v} / \mathrm{v}) \\
+5 \mathrm{ml} \text { methanol }\end{array}$ \\
\hline
\end{tabular}


Table 3. Characteristics of the bulk organic matter. POC: particulate organic carbon; PON: particulate organic nitrogen; Xeno: xenophyophore sample; Sed: reference sediment; Sed-bis: sediments from the same mesotrophic site, data from Relexans et al. (1996); nd: non determined; dw: dry weight

\begin{tabular}{|lccccc|}
\hline & $\begin{array}{c}\text { POC } \\
\left(\mathrm{mg} \mathrm{g} \mathrm{dw}^{-1}\right)\end{array}$ & $\begin{array}{c}\text { PON } \\
\left(\mathrm{mg} \mathrm{g} \mathrm{dw}^{-1}\right)\end{array}$ & $\begin{array}{c}\text { C/N } \\
\text { ratio }\end{array}$ & $\begin{array}{c}\Sigma \text { free lipids } \\
\left(\mathrm{mg} \mathrm{g} \mathrm{dw}^{-1}\right)\end{array}$ & $\begin{array}{c}\Sigma \text { free lipids/ } \\
\text { POC (\%) }\end{array}$ \\
\hline Xeno & 6.6 & 0.6 & 11 & 0.78 & 12 \\
Sed & 4.1 & 0.33 & 12.4 & 0.22 & 5.4 \\
Sed-bis & $3.7-4.3$ & nd & nd & $0.20-0.34$ & $4.6-8.9$ \\
\hline
\end{tabular}

important compounds in animals and plants but absent in bacteria, were 8 and 6 times less abundant in sed (3 and $4 \mu \mathrm{g} \mathrm{g}$

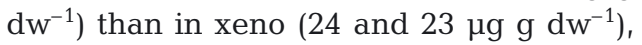
respectively. Among the reserve lipids, TAG, with a lower specific gravity than WE, are by far the commonest storage lipid in benthic animals (Pond et al. 2000). This can explain the minor importance of WE

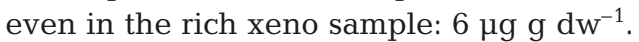
The detrital part of the organic matter essentially consists of lipids resulting from

sample are comparable with those of sediments from the eutrophic site sampled during the same cruise (J. Laureillard et al. unpubl.), pointing to the particular richness in organic matter of the xenophyophores.

\section{Lipid classes}

The concentrations of intact lipids, determined using Iatroscan TLC/FID, are presented in Table 4 for xeno and sed samples. They displayed very different lipid class proportions and, for the same class, lipids were always considerably more abundant in the xeno sample. Lipids originate from living organisms and detrital matter. Polar lipids, which consist of phospholipids (PL) and glycolipids (GL) were by far the major constituents of the total lipid extract. They accounted for 518 and $167 \mu \mathrm{g} g$ dry weight $(\mathrm{dw})^{-1}$, for xeno and sed samples, respectively. These high contents in labile compounds, representative of living populations due to their rapid turnover after cell death, underline that the 2 samples were hotspots of living organisms, especially the xenophyophore-containing sample. TAG and sterols,

Table 4. Concentration and percentage composition of lipid classes. HC: hydrocarbons; WE: wax esters; FFA: free fatty acids; TAG: triacylglycerols; ALC: alcohols; ST: sterols; DAG: diacylglycerols; MAG: monoacylglycerols; PL: phospholipids; GL: glycolipids; CHL: chlorophylls; Xeno: xenophyophore sample; Sed: reference sediment

\begin{tabular}{|lccccc|}
\hline & \multicolumn{2}{c}{ Xeno } & & \multicolumn{2}{c|}{ Sed } \\
\cline { 2 - 3 } \cline { 5 - 6 } & $\left(\mu \mathrm{g} \mathrm{dw}^{-1}\right)$ & $(\%)$ & & $\left(\mu \mathrm{g} \mathrm{dw}^{-1}\right)$ & $(\%)$ \\
\hline HC & 37 & 4.7 & 7 & 3.2 \\
WE & 6 & 0.8 & 0 & 0 \\
FFA & 56 & 0.1 & 20 & 9 \\
TAG & 24 & 3.1 & 3 & 1.4 \\
ALC & 5 & 0.6 & 4 & 1.8 \\
ST & 23 & 2.9 & & 4 & 1.8 \\
DAG & 8 & 1 & 0 & 0 \\
MAG & 88 & 11.2 & 10 & 4.5 \\
PL & 321 & 40.9 & 101 & 45.7 \\
GL & 197 & 25.1 & 66 & 29.9 \\
CHL & 19 & 2.4 & 6 & 2.7 \\
& & & & & \\
\hline
\end{tabular}

degradation of glycerides (PL, GL and TAG), including diacylglycerols (DAG), monoacylglycerols (MAG), and free fatty acids (FFA). These degradation lipids occurred in higher proportions in the xeno sample $(19.3 \%)$ than in the sed sample $(13.5 \%)$, along with more DAG and MAG (1.0 and $11.2 \%$, compared with 0 and $4.5 \%$, respectively). Nevertheless, a lower abundance of FFA is observed for the sample of xenophyophores: 7.1 vs $9.0 \%$.

Table 5. Concentration and percentage composition of fatty acids (FA) in phospholipids (PL). Xeno: xenophyophore sample; sed: reference sediment

\begin{tabular}{|c|c|c|c|c|}
\hline \multirow[b]{2}{*}{$\begin{array}{l}\text { Fatty } \\
\text { acids }\end{array}$} & \multicolumn{2}{|c|}{- Xeno -} & \multicolumn{2}{|c|}{${ }_{-}$Sed } \\
\hline & $\begin{array}{c}\text { Concentration } \\
\left(\mu \mathrm{g} \mathrm{dw}^{-1}\right)\end{array}$ & $\begin{array}{c}\text { Percentage } \\
(\%)\end{array}$ & $\begin{array}{l}\text { Concentration } \\
\left(\mu \mathrm{g} \mathrm{dw}^{-1}\right)\end{array}$ & $\begin{array}{c}\text { Percentage } \\
(\%)\end{array}$ \\
\hline $\mathrm{i}-14$ & 0.085 & 0.8 & 0.011 & 0.4 \\
\hline $14: 0$ & 0.49 & 4.8 & 0.19 & 6.7 \\
\hline i-15 & 0.41 & 3.9 & 0.052 & 1.8 \\
\hline$a-15$ & 0.53 & 5.2 & 0.095 & 3.3 \\
\hline $15: 0$ & 0.25 & 2.5 & 0.11 & 3.9 \\
\hline i-16 & 0.17 & 1.7 & 0.031 & 1.1 \\
\hline $16: 0$ & 1.56 & 15.2 & 0.76 & 26.9 \\
\hline $16: 1 \omega 10$ & 0.51 & 5.0 & 0.33 & 11.6 \\
\hline $16: 1 \omega 7$ & 1.38 & 13.4 & 0.18 & 6.5 \\
\hline $16: 1 \omega 5$ & 0.44 & 4.2 & 0.026 & 0.9 \\
\hline i-17 & 0.11 & 1.0 & 0.015 & 0.5 \\
\hline a-17 & 0.067 & 0.6 & 0.0 & 0.0 \\
\hline $17: 0$ & 0.12 & 1.2 & 0.038 & 1.4 \\
\hline $17 \Delta$ & 0.14 & 1.3 & 0.049 & 1.7 \\
\hline 18:0 & 0.29 & 2.8 & 0.26 & 9.2 \\
\hline $18: 1 \omega 9$ & 0.62 & 6.1 & 0.30 & 10.5 \\
\hline $18: 1 \omega 7$ & 1.53 & 14.9 & 0.13 & 4.7 \\
\hline $18: 2 \omega 6$ & 0.074 & 0.7 & 0.020 & 0.7 \\
\hline 20:0 & 0.074 & 0.7 & 0.012 & 0.4 \\
\hline $20: 2 \omega 6$ & 0.080 & 0.8 & 0.005 & 0.2 \\
\hline $20: 3 \omega 6$ & 0.0 & 0.0 & 0.012 & 0.4 \\
\hline $20: 4 \omega 6$ & 0.25 & 2.4 & 0.022 & 0.8 \\
\hline $20: 3 \omega 3$ & 0.039 & 0.4 & 0.0 & 0.0 \\
\hline 22:0 & 0.030 & 0.3 & 0.0 & 0.0 \\
\hline $20: 5 \omega 3$ & 0.42 & 4.0 & 0.073 & 2.6 \\
\hline $22: 1 \omega 9$ & 0.063 & 0.6 & 0.0 & 0.0 \\
\hline $22: 4 \omega 6$ & 0.0 & 0.0 & 0.004 & 0.1 \\
\hline 24:0 & 0.085 & 0.8 & 0.045 & 1.6 \\
\hline $24: 1 \omega 9$ & 0.12 & 1.2 & 0.0 & 0.0 \\
\hline $22: 6 \omega 3$ & 0.35 & 3.4 & 0.056 & 2.0 \\
\hline
\end{tabular}




\section{Phospholipids (PL)}

It is in this lipid class that the FA characteristic of living organisms are found. The main FA occurring in the xeno and the sed samples (Table 5) were 16:0 (15.2 and $26.9 \%$, respectively), $16: 1 \omega 7$ (13.4 and $6.5 \%$, respectively), $18: 1 \omega 7$ (14.9 and $4.7 \%$, respectively), 18:1 $\omega 9$

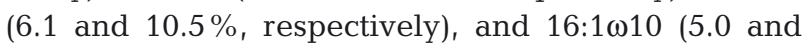
$11.6 \%$, respectively). The sum of the saturated acids considered as bacterial (branched, cyclic, and oddnumbered FA) represented a higher percentage in the xeno sample than in the reference sediment (18.2 vs $14.1 \%$ ). Relative abundances of the monounsaturated FA were more variable. Deep benthic organisms typically have a low level of polyunsaturated fatty acids (PUFA) and $\mathrm{C}_{20}$ and $\mathrm{C}_{22}$ PUFA are present only as traces (Reinhardt \& Van Vleet 1986). However, they contributed significantly to the deep-sea xeno and sed samples, with a higher level in the xeno sample $(11.7 \%$ vs $6.8 \%$ ). Moreover, the PUFA distribution was not identical in the xeno and the sed samples.

\section{Triacylglycerols (TAG)}

Fatty acids in the diet are partly stored in reserve lipids, and the analysis of their constituent fatty acids can be used to investigate predator-prey relationships. The main fatty acids in TAG for the xeno and the sed samples were 16:0 (24.5 and 22.5\%, respectively), 18:1 $1 \omega 9$ (8.8 and $11.6 \%$, respectively), and $18: 1 \omega 7$ (13.6 and 6.9\%, respectively), (Table 6). The saturated and monounsaturated FA were more abundant in the xeno sample, whereas PUFA made up a larger proportion in the sed sample. Palmitoleic acid, in particular, was more abundant in the xeno sample at 8.7 vs $2.8 \%$ for the reference sediment. The contents of the 2 essential PUFA, 20:5 $\omega 3$ and 22:6 63 , were higher in the sed sample (3.5 and $1.0 \%$, respectively) than in the xeno sample (1.8 and $0.8 \%$, respectively). The $\mathrm{C}_{15}$ and $\mathrm{C}_{17}$ acids, branched or not, are considered as bacterial markers. All of them were in higher proportions in the xeno sample.

\section{Sterols}

Sterols are encountered in higher plants, animals and algae, but not in most bacteria. Their much higher abundance in the xeno sample (Table 7) reflected an important concentration of the former organisms, or their remains, in this sample. The main animal sterol is usually cholesterol, whereas this sterol generally accounts only for a small proportion of phytosterols, which varies according to the species. The high amounts of cholesterol $(28.0 \%)$ in the xeno sample, where it was the most important sterol, and in the sed sample $(24.4 \%)$, can be ascribed mainly to benthic ani-
Table 6. Concentration and percentage composition of fatty acids (FA) in triacylglycerols (TAG). Xeno: xenophyophore sample; Sed: reference sediment

\begin{tabular}{|c|c|c|c|c|}
\hline \multirow[b]{2}{*}{$\begin{array}{l}\text { Fatty } \\
\text { acids }\end{array}$} & \multicolumn{2}{|c|}{$\longrightarrow$ Xeno -} & \multirow{2}{*}{$\begin{array}{c}\text { Sed } \\
\text { Concentration } \\
\left(\mu g g_{d w^{-1}}\right)\end{array}$} & \multirow[b]{2}{*}{$\begin{array}{c}\text { Percentage } \\
(\%)\end{array}$} \\
\hline & 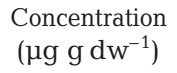 & $\begin{array}{c}\text { Percentage } \\
(\%)\end{array}$ & & \\
\hline $14: 0$ & 0.43 & 6.4 & 0.055 & 3.7 \\
\hline i-15 & 0.16 & 2.4 & 0.012 & 0.8 \\
\hline a-15 & 0.11 & 1.6 & 0.014 & 1.0 \\
\hline $15: 0$ & 0.20 & 2.9 & 0.045 & 3.0 \\
\hline i-16 & 0.12 & 1.9 & 0.013 & 0.9 \\
\hline $16: 0$ & 1.64 & 24.5 & 0.33 & 22.5 \\
\hline $16: 1 \omega 10$ & 0.23 & 3.4 & 0.12 & 7.9 \\
\hline $16: 1 \omega 7$ & 0.58 & 8.7 & 0.042 & 2.8 \\
\hline $16: 1 \omega 5$ & 0.17 & 2.6 & 0.011 & 0.7 \\
\hline i-17 & 0.090 & 1.3 & 0.012 & 0.8 \\
\hline $\mathrm{a}-17$ & 0.027 & 0.4 & 0.0 & 0.0 \\
\hline $17: 0$ & 0.12 & 1.8 & 0.023 & 1.5 \\
\hline $17 \Delta$ & 0.16 & 2.3 & 0.0 & 0.0 \\
\hline 18:0 & 0.29 & 4.3 & 0.12 & 8.1 \\
\hline $18: 1 \omega 9$ & 0.59 & 8.8 & 0.17 & 11.6 \\
\hline $18: 1 \omega 7$ & 0.91 & 13.6 & 0.10 & 6.9 \\
\hline $18: 2 \omega 6$ & 0.047 & 0.7 & 0.022 & 1.5 \\
\hline $18: 2 \omega 4$ & 0.026 & 0.4 & 0.0 & 0.0 \\
\hline $18: 3 \omega 3$ & 0.0 & 0.0 & 0.005 & 0.3 \\
\hline $20: 0$ & 0.054 & 0.8 & 0.015 & 1.0 \\
\hline $20: 1 \omega 9$ & 0.15 & 2.2 & 0.038 & 2.6 \\
\hline $20: 2 \omega 6$ & 0.13 & 1.9 & 0.048 & 3.2 \\
\hline 21:0 & 0.0 & 0.0 & 0.004 & 0.2 \\
\hline $20: 4 \omega 6$ & 0.085 & 1.3 & 0.12 & 8.2 \\
\hline $22: 0$ & 0.044 & 0.7 & 0.022 & 1.5 \\
\hline $20: 5 \omega 3$ & 0.12 & 1.8 & 0.053 & 3.5 \\
\hline $22: 1 \omega 9$ & 0.029 & 0.4 & 0.005 & 0.3 \\
\hline $24: 0$ & 0.081 & 1.2 & 0.042 & 2.8 \\
\hline $24: 1 \omega 9$ & 0.033 & 0.5 & 0.011 & 0.8 \\
\hline $22: 6 \omega 3$ & 0.055 & 0.8 & 0.015 & 1.0 \\
\hline $26: 0$ & 0.033 & 0.5 & 0.013 & 0.9 \\
\hline
\end{tabular}

mals. Marine sterols attributed to diatoms were repre-

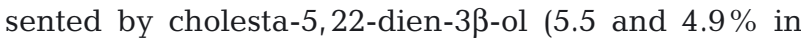
xeno and sed samples, respectively), 24-methylcholesta-5,24(28)-dien-3 $\beta$-ol (3.7 and 4.6\%) and 24-

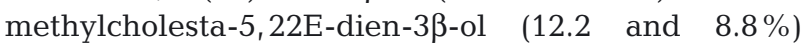
(Volkman et al. 1980a, Volkman 1986). The last sterol is considered as a diatom biomarker in productive waters, even though it also occurs in high levels in most Prymnesiophyceae. 4-Methyl sterols often occur in dinoflagellates in significant amounts (Nichols et al. 1983). Prymnesiophytes of the genus Pavlova can be an important source of these compounds (Volkman et al. 1990), while diatoms are usually a marginal source (Volkman et al. 1993). Thus, an algal origin can be attributed to $4 \alpha, 23,24$-trimethyl-5 $\alpha$-cholest-22E-en$3 \beta$-ol (dinosterol), which accounts for 5.0 and $4.7 \%$ of total sterols in xeno and sed samples, respectively. Otherwise, the major sterols found in vascular plants are 24-ethylcholest-5-en-3 $\beta$-ol, 24-ethylchol-

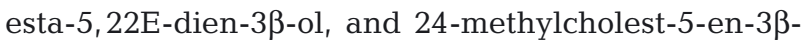


Table 7. Concentration and percentage composition of sterols. Xeno: xenophyophore sample; Sed: reference sediment; M: marine sterol; $\mathrm{T}$ : terrigenous sterol; A: animal sterol

\begin{tabular}{|c|c|c|c|c|c|c|}
\hline \multirow[b]{2}{*}{ Sterols } & \multirow[b]{2}{*}{ Common name } & \multicolumn{2}{|c|}{${ }_{-}$Xeno -} & \multicolumn{2}{|c|}{$\longrightarrow$ Sed $\longrightarrow$} & \multirow{2}{*}{$\begin{array}{c}\text { Sterol } \\
\text { attribution } \\
\text { here }\end{array}$} \\
\hline & & $\begin{array}{l}\text { Concentration } \\
\left(\mu g \mathrm{~g} \mathrm{dw}^{-1}\right)\end{array}$ & $\begin{array}{l}\text { Percentage } \\
\quad(\%)\end{array}$ & $\begin{array}{l}\text { Concentration } \\
\left(\mu \mathrm{g} \mathrm{dw}^{-1}\right)\end{array}$ & $\begin{array}{l}\text { Percentage } \\
(\%)\end{array}$ & \\
\hline $\begin{array}{l}\text { 27-nor-24-methylcholesta- } \\
5,22 \text {-dien-3 } \beta \text {-ol }\end{array}$ & & 0.070 & 1.0 & 0.019 & 1.1 & \\
\hline Cholesta-5,22E-dien-3 $\beta$-ol & Dehydrocholesterol & 0.39 & 5.5 & 0.089 & 4.9 & M \\
\hline $5 \alpha$-cholest-22E-en $3 \beta$-ol & Dehydrocholestanol & 0.033 & 0.5 & 0.016 & 0.9 & \\
\hline Cholest-5-en-3 $\beta$-ol & Cholesterol & 1.98 & 28.0 & 0.44 & 24.4 & A \\
\hline $5 \alpha$-cholestan- $3 \beta$-ol & Cholestanol & 0.16 & 2.3 & 0.038 & 2.1 & \\
\hline 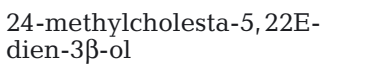 & Brassicasterol or epimer & 0.86 & 12.2 & 0.16 & 8.8 & M \\
\hline $\begin{array}{l}\text { 24-methyl-5 } \alpha \text {-cholest-22E- } \\
\text { en-3 } 3 \text {-ol }\end{array}$ & Brassicastanol or epimer & 0.068 & 1.0 & 0.020 & 1.1 & \\
\hline 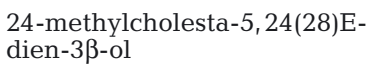 & 24-methylenecholesterol & 0.26 & 3.7 & 0.083 & 4.6 & M \\
\hline 24-methylcholest-5-en-3 $\beta$-ol & 24-methylcholesterol & 0.24 & 3.4 & 0.056 & 3.1 & $\mathrm{~T}$ \\
\hline 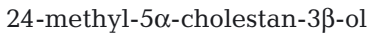 & 24-methylcholestanol & 0.019 & 0.3 & 0.007 & 0.4 & \\
\hline 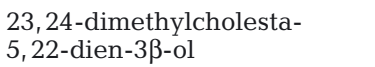 & & 0.12 & 1.7 & 0.025 & 1.4 & \\
\hline $\begin{array}{l}\text { 24-ethylcholesta-5, 22E- } \\
\text { dien-3ß-ol }\end{array}$ & Stigmasterol or epimer & 0.42 & 5.9 & 0.16 & 8.9 & $\mathrm{~T}$ \\
\hline $\begin{array}{l}\text { 23,24-dimethylcholest-5- } \\
\text { en-33-ol }\end{array}$ & & 0.15 & 2.1 & 0.0 & 0.0 & \\
\hline 24-ethylcholest-5-en-3 $\beta$-ol & 24-ethylcholesterol & 1.62 & 23.0 & 0.55 & 30.2 & $\mathrm{~T}$ \\
\hline 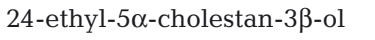 & 24-ethylcholestanol & 0.15 & 2.1 & 0.067 & 3.7 & \\
\hline $\begin{array}{l}\text { 24-ethylcholesta-5, 24(28)Z- } \\
\text { dien-3ß-ol }\end{array}$ & $\begin{array}{l}\text { Stigmasta-5, 24(28)- } \\
\text { dien-3ß-ol }\end{array}$ & 0.17 & 2.4 & 0.0 & 0.0 & \\
\hline $\begin{array}{l}4 \alpha, 23,24 \text {-trimethyl- } 5 \alpha \text { - } \\
\text { cholest-22E-en- } 3 \beta \text {-ol }\end{array}$ & Dinosterol & 0.35 & 5.0 & 0.084 & 4.7 & M \\
\hline
\end{tabular}

ol. Here, they accounted for $23.0,5.9,3.4 \%$ and 30.2 , 8.9, $3.1 \%$ for the xeno and sed samples, respectively. They are considered as representative of higher plants, in sediments from areas of low productivity, even though several microalgae synthesize these compounds (Volkman et al. 1998). The ratios of these 3 sterols were similar in the xeno sample (1:1.7:6.8) and in the sed sample (1:2.9:9.7), which points to a common source, and similar degradation rates. Since comparable ratios were found in many higher plants and in sediments where the sedimentary inputs were essentially land-derived organic matter (Volkman 1986), these 3 sterols most likely derived from terrigenous sources at the study site, coming from aeolian inputs of African vegetation (J. Laureillard et al. unpubl).

\section{DISCUSSION}

\section{Metazoa-xenophyophore association in the xeno sample}

Generally, the presence of xenophyophores on the deep-sea floor plays a significant role in locally structuring metazoan community organization. For Pacific protists, in addition to the inside colonization of the test, an increase in the abundance of metazoa is observed beneath the xenophyophore tests and in their folds (Gooday 1984, Levin et al. 1986, 1991b, Levin \& Thomas 1988, Levin 1991, 1994). Therefore an important issue required for interpreting our results is discovering whether the organic matter analyzed in the xeno sample corresponds to the xenophyophores themselves or to the xenophyophores and the associated metazoa. In the northeastern Atlantic Ocean, near our study site, only $6 \%$ of the tests of the xenophyophore Aschemonella ramuliformis broken open with small apertures were occupied by metazoans (Gooday 1984), whereas $100 \%$ of the xenophyophore tests in the eastern Pacific were inhabited by metazoans (Levin et al. 1986, Levin \& Thomas 1988). In the same way, in Syringammina corbicula, distinct apertures are absent (Richardson 2001). Only a single harpacticoid copepod nauplius was found associated with the stercomes of this species, and the test was replete with stercomes and cytoplasm. Given the fragility of xenophyophore tests in the North Atlantic (Tendal \& Gooday 1981, Gooday \& Tendal 1988, Gooday 1991, 1996), one could suppose that the small metazoans succeeding in the penetration of the tests 
cause them to break up when they grow. Consequently, owing to the low level of internal colonization of $S$. corbicula, we can consider that the lipids analysed belonged essentially to these protists. Moreover, S. Richardson (pers. comm.) thought that it would be possible to attribute the high lipid content of the xeno sample to the developed membrane system of $S$. corbicula, which would account for the high amount of PL observed (Table 4), in spite of the small volume of protoplasts of xenophyophores (1 to $5 \%$ for Syringaminna sp.; Levin \& Gooday 1992).

According to the aforementioned literature, the xeno sample included the protoplasms, the stercomes, and the agglutinated tests, which together make up the animals themselves. It also included, in the folds of the tests, sedimenting particles as well as resuspended sediment due to a weak bottom nepheloid layer (Vangriesheim et al. 1993), and, maybe, for a very minor part, some associated metazoans. Consequently, the lipid composition of the xeno sample will reflect these different sources.

\section{Influence of xenophyophores on organic matter composition}

Xenophyophores were richer in POC, PON and lipid contents than the reference sediment (Table 3). Moreover, this increase corresponded to an organic matter much richer in lipids, as inferred from the values of $\Sigma$ free lipids/POC ratio. PL were the major lipid class (Table 4), and their higher quantity in the xeno sample points to a high concentration of living benthic organisms.

\section{Phytoplanktonic inputs and freshness of the collected particles}

Passive modifications in the flow due to shapes and sizes of the reticulations in the xenophyophore tests, active trapping and selection of particles (Levin \& Thomas 1988) may enhance local particle flux and its composition, leading to fresher and more nutritive sediments collected by the protozoan. Evidence of particle freshness inside and in the immediate vicinity of the xenophyophore tests was previously provided by an enhancement of excess ${ }^{234} \mathrm{Th}$ (Levin et al. 1986, Levin 1991). Labile compounds constituting chloroplasts (CHL and GL) were more abundant in the xeno sample (197 and $19 \mu \mathrm{g} \mathrm{g}^{-1}$ vs 66 and $6 \mu \mathrm{g} \mathrm{g}^{-1}$ for the reference sediment, respectively), which corroborates Levin's findings and points to the increase of sedimentation near the tests, associated with a selective collection of fresh nutritious phytoplanktonic particulate matter (Table 4). The relative proportions of sterols principally indicative of the 3 possible origins, higher plants, ani-

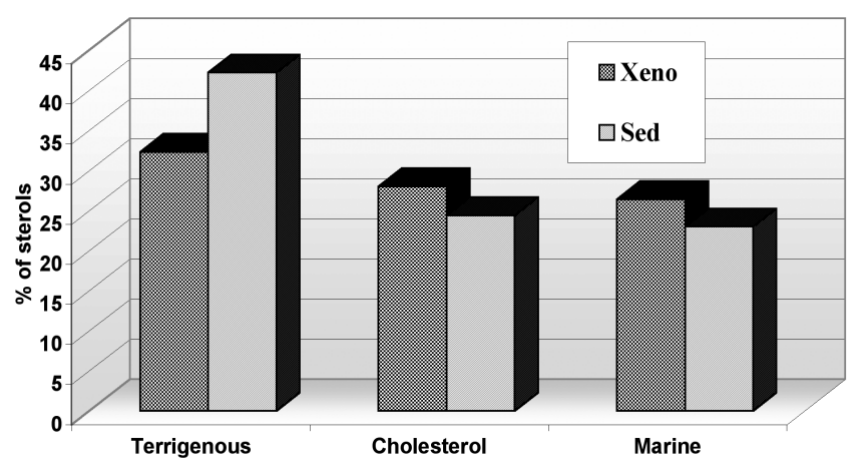

Fig. 2. Distribution of sterols according to their origin in xenophyophores (Xeno) and in sediment free of protists (Sed). Terrigenous sterols: 24 -ethylcholest-5-en-3 $\beta$-ol, 24 -ethylcholesta-

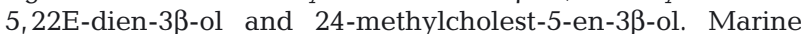
sterols: 24-methylcholesta-5,22E-dien-3 $\beta$-ol, cholesta-5, 22E-

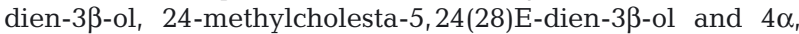
23, 24-trimethyl- $5 \alpha$-cholest-22-en-3 $\beta$-ol

mals and phytoplankton (Table 7), are reported in Fig. 2. Differences appeared between the sed and xeno samples, where cholesterol, an animal sterol, and marine sterols prevailed. In addition, the latter sample included less poorly nutritious particles originating from continental inputs, as evidenced by a lower percentage of terrigenous sterols (Table 7). The higher $\mathrm{C} / \mathrm{N}$ ratio (Table 3 ) for the sed sample also suggested an organic matter which was more continental and more refractory (Stein 1991) than in the xeno sample, in agreement with the preceding results. The greater phytoplanktonic imprint and lower terrigenous imprint in the particles on the test of xenophyophores than in the reference sediment evidenced an active selection of nutritious particles by the protists.

However, the percentages of GL and CHL, representative of the phytoplanktonic inputs, were lower in the xeno sample than in the sed sample (Table 4) because of dilution of these fresh particles with relatively large quantities of detrital matter in xenophyophores: already-digested particles packed in stercomes and stored inside the test on one hand, and the organic part of the test which may include as much lipid as the living part of the animal (DeLaca 1986), on the other hand. This detrital matter constitutes a source of lipids much poorer in GL, CHL, and PL than fresh phytoplankton detritus. Compared with the sed sample, a large amount of degradation lipids (DAG + MAG + FFA) was observed in the xeno sample (152 vs $30 \mu \mathrm{g} \mathrm{g} \mathrm{dw}^{-1}$ ), leading also to a much higher percentage (19.3 vs $13.5 \%$ ). The percentages of DAG and MAG were considerably higher in the xeno sample, while FFA, a lipid class indicative of more decayed organic matter, were less abundant. Consequently, the xeno sample corresponded to fresher sedimented phytoplankton and less decayed detrital organic matter than the sed sample. 
Living organism presence: bacteria and xenophyophore imprint

Phospholipids, are the most labile part of the organic matter (Harvey et al. 1986), and can give an overview of the living organisms in a sample. PL components of membranes accounted for a large part of total lipids (Table 4). Here, they originated from animals, bacteria, and probably from only a very small amount of living algae. Indeed, even in areas with high sedimentation rates, no algal PL could be identified in surficial sediments at deep sites (Pinturier-Geiss et al. 2001). Phospholipid fatty acids (PLFA) (Table 5) can give an insight into the different sources of living or fresh organic matter, since some fatty acids are specific to bacteria, algae or animals.

Branched-chain fatty acids, and especially iso and anteiso $\mathrm{C}_{15}$ and $\mathrm{C}_{17}$, are commonly used as bacterial markers, and they occur widely in bacteria (Kaneda 1991). Cyclopropanyl fatty acids $\left(\Delta \mathrm{C}_{17}\right.$ and $\left.\Delta \mathrm{C}_{19}\right)$ are also characteristic of bacteria (Guckert et al. 1986, Balkwill et al. 1998). All these bacterial markers accounted for a significant part of the PL for the xeno sample (Fig.3), 14.7 vs $8.9 \%$ for the sed sample, pointing to an important development of bacterial communities in the xenophophyore structures. This feature is corroborated by the finding that microbial respiratory activity associated with xenophyophore samples was 5 to 6 times higher than that measured in control sediments (Sibuet et al. 1993). Futhermore, vaccenic acid $(18: 1 \omega 7)$ has very often been attributed to sedimentary bacteria (Perry et al. 1979, Gillan \& Johns 1986) and also to bacteria attached to particles in surface waters, where it covaried with branched fatty acids (Saliot et
$\%$ FA of PL : Xeno
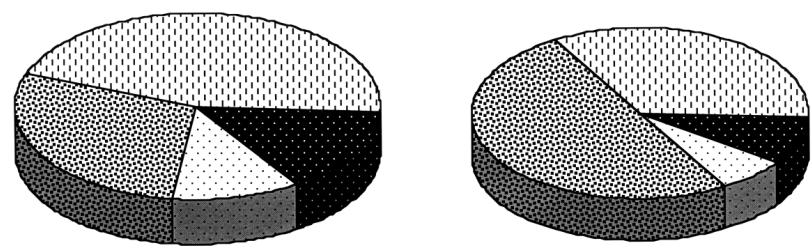

Sed

Linear saturated
Monounsaturated
Branched + Cyclics
PUFA

Fig. 3. Percentage distribution of fatty acids (FA) of phospholipids (PL) in xenophyophores (Xeno) and in sediment free of these protists (Sed). PUFA: polyunsaturated fatty acids al. 1997). Although 16:1 15 is found in very small quantities in diatoms (Dunstan et al. 1994), this fatty acid is considered as a bacterial marker (Desvilettes et al. 1997). Indeed, it was found in PLFA of anoxic sediments, where eukaryotic participation was very weak (Rajendran et al. 1992, 1994, 1995), and in bacterial cultures (Lambert et al. 1983, Carballeira et al. 1995, 1997). Odd-carbon-numbered normal fatty acids in the range $\mathrm{C}_{13}$ to $\mathrm{C}_{17}$ are also contributed by bacteria (Volkman et al. 1980b, Jantzen 1984, Harvey 1997). Here, they were represented by $n-15: 0$ and $n-17: 0$. The distribution of bacterial markers can characterize bacterial assemblages. In Fig. 4 we use the relative percentages of all these compounds originating from bacteria and their ratios to compare the bacterial populations of the 2 samples. The patterns are very different, highlighting the development of specific bacteria within the xenophyophores, probably on stercomes.

The higher quantity of PUFA observed in the xeno PLFA compared to the sed sample (Fig. 3) may correspond to a higher biomass of animals or deep-sea bacteria, since these bacteria can be rich in PUFA (Delong \& Yayanos 1986). They can account for the PUFA

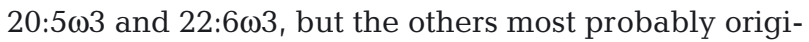
nated from xenophyophores. Non-bacterial PLFA observed in the xeno sample and absent or rare in the reference sediment could be attributed to xeno-

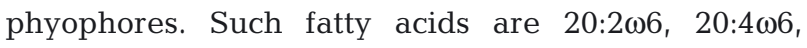

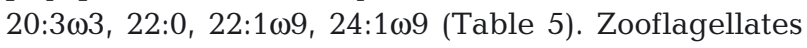
and ciliates are a source of $\omega 6$ PUFA (Zhukova \& Kharlamenko 1999) which are considered as protist markers (Vestal \& White 1989, Desvilettes et al. 1997). Indeed, in the total fatty-acid pattern of the aggluti-

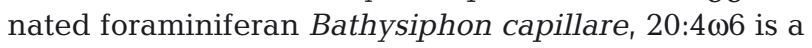

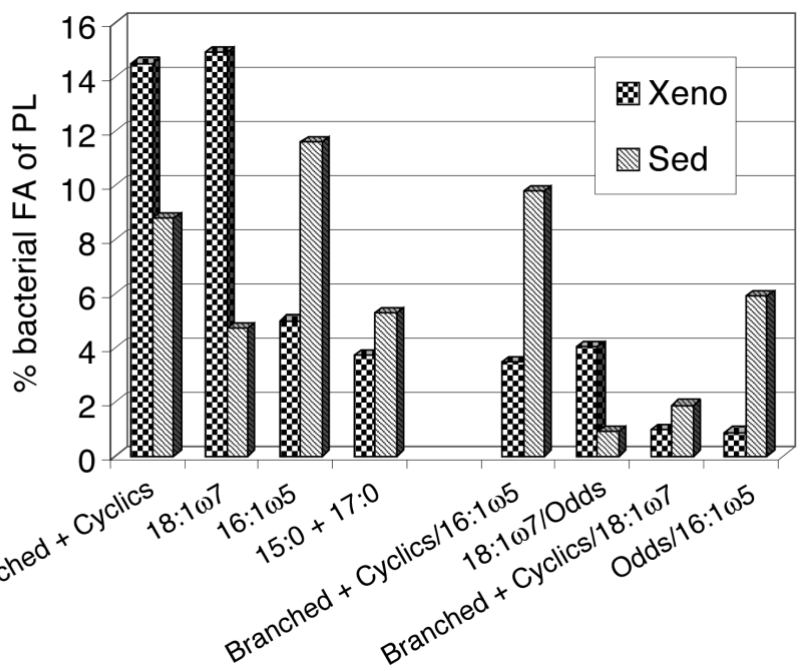

Fig. 4. Distribution of bacterial fatty acids (FA) of phospholipids (PL) in xenophyophores (Xeno) and in sediment free of these protists (Sed) 
prominent compound (Gooday et al. 2002). However, these $\omega 6$ acids have also been identified in a wide range of deep-sea fauna (Ginger et al. 2000, Pond et al. 2002, Howell et al. 2003). Moreover, 2 sterols (23, 24-dimethylcholest-5-en-3 $\beta$-ol and 24-ethylcholesta5,24 [28]-dien-3 $\beta$-ol) (Table 7) were found neither in the sed, nor in sediments of eutrophic and oligotrophic sites of the same area. They might constitute, with

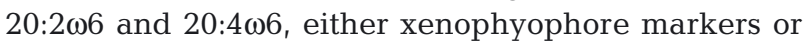
specifically associated organism markers.

\section{Trophic relationships}

An especially high level of TAG, reserve lipids which are found in senescent phytoplankton or in animals as storage lipids, was observed in the xeno sample (Table 4) and most likely represents an input from the xenophyophores. The distribution of fatty acids in TAG is representative of diet and may throw light on the feeding habits of the dominant fauna, xenophyophores. However, little information is available regarding their nutritional habits, and we only have hypotheses.

In the TAG of the xeno sample, the contents of bacterial markers-(branched and cyclic fatty acids) (Fig. 5), as well as the fatty acid 18:1 107 (Fig. 6) - were much higher than in the sed sample. Accordingly, xenophyophores must be considered as bacterivorous. The fact that similar fatty acid patterns and acid ratios were observed in the TAG (Fig. 6) and the PL (Fig. 4) of the xeno sample highlighted the fact that xenophyophores fed on a particular assemblage, different from the bacteria growing in the ambient seafloor sediments (sed). This feature pointed to the same origin for

$\%$ FA of TAG : Xeno
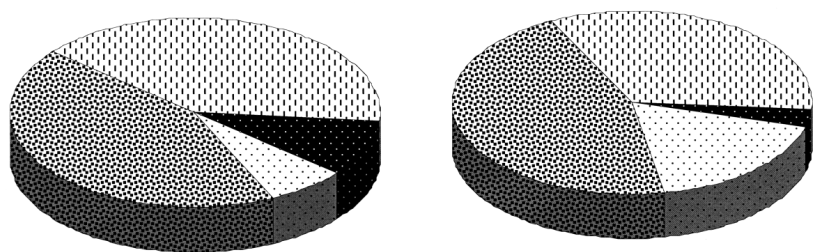

: Linear saturated Monounsaturated Branched + Cyclics Q PUFA

Fig. 5. Percentage distribution of fatty acids (FA) of triacylglycerols (TAG) in xenophyophores (Xeno) and in sediment free of these protists (Sed). PUFA: polyunsaturated fatty acids the ingested bacteria and the bacteria colonizing the stercomes. In contrast, for the sed sample, the different patterns of bacterial fatty acids in PL (Fig. 4) and TAG (Fig. 6) indicated selective predation of sedimentary bacteria by bacterivorous organisms in mesotrophic sediments. The higher level of the acid 16:1 107 frequent in bacteria in TAG of the xeno sample (8.7 vs $2.8 \%$ for sed; Table 6) might also suggest that the xenophyophore diet was richer in bacteria than the diet of other protists at the mesotrophic site.

These results support Tendal's hypothesis (Tendal 1979) about xenophyophore nutrition, according to which xenophyophores cultivate bacteria in the stercomes, probably to maintain a food-reserve rich in amino-acids and other labile nutritive elements, in otherwise food-poor settings. In the agglutinating foraminiferans Pelosina cf. arborescens and a mudwalled astrorhizinid which lack stercomes, Levin et al. (1991a) found no evidence either of selective collection of fresh particles, microbial cultivation or bacteria enhancement associated with the tests. Thus, this absence of an increase in the microbial abundance might be attributed to the lack of stercomes under the tests. The substantial bacterial component in the diet of the infaunal agglutinated foraminiferan Bathysiphon capillare, a species with stercomes, is considered as originating from the bacteria associated with the ingested fine-grained sediment (Gooday et al. 2002).

The whole TAG analysed may not originate solely from the xenophyophores; a part of TAG might derive from associated metazoans. These colonizers could then feed on non-protected stercomes. Consequently, in the xeno sample, a part of TAG containing bacterial markers could originate from metazoans fed on stercomes. Several observations reported elsewhere cor-

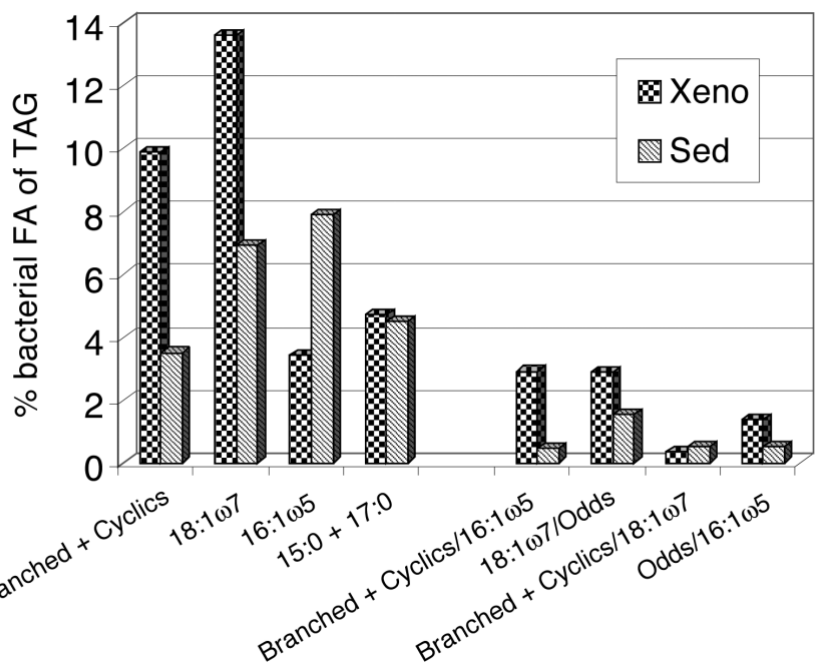

Fig. 6. Distribution of bacterial fatty acids (FA) of triacylglycerols (TAG) in xenophyophores (Xeno) and in sediment free of these protists (Sed) 
roborate this finding. Meiofauna with stercome-filled guts have been collected in the tubes of xenophyophore tests (Gooday 1991, Levin \& Gooday 1992) and, more precisely, C. Huggett observed a great number of harpacticoid copepods with stercome-filled guts inside the tests of Syringammina sp. (Levin \& Gooday 1992). The occurrence of $\omega 6$ PUFA probably originating from xenophyophores in TAG of the xeno sample evidenced the presence of some predators of these protists associated with them. These observations demonstrate that metazoans join with xenophyophores in a trophic relationship (Levin \& Gooday 1992). Bacterial populations on stercomes could constitute an additional food source for xenophyophores and for associated metazoans.

\section{Conclusions}

Xenophyophore presence on deep-sea sediments induced environmental modifications, especially a higher abundance of bacteria, which led to sites of great biological activity, as shown by lipid content and composition of the xenophyophores analysed compared with a reference sediment. On the reticulated tests, an increase of fresh sedimentary particles, richer in phytoplanktonic labile compounds (GL and CHL) and poorer in refractory terrigenous material, highlighted a selection in the collection of particles by xenophyophores. In addition, the huge quantity of already-digested particles, stored under the test as stercomes, was indicated from the greater amounts of degradation lipids, DAG, MAG, and to a lesser extent FFA.

Xenophyophores seemed to 'cultivate' bacteria on stercomes under their tests and feed on them to supplement their diet with this highly nutritious food source when the arrival of sedimentary particles is not sufficient. The consumption of these bacteria was inferred from the significance of bacterial markers in TAG of the xeno sample, which essentially represented their reserve lipids, and thereby their diet. The bacterial assemblage in xenophyophores was different to that of the reference sediment, highlighting the development of different bacteria on fecal pellets.

The colonization of metazoans in the folds of xenophyophore tests would occur due to the vicinity of substantial food sources: input of sedimentary phytoplankton and bacteria growing on stercomes. They could take advantage of the latter source of nutritious food after the rupture of the tests due to animal intrusion.

Two $\omega 6$ fatty acids and 2 sterols were only detected in the xenophyophore sample, and they might be biomarkers of xenophyophores or organisms associated only with these animals.
Acknowledgements. We thank Julien Kohn for a part of the analytical experimental work, Joëlle Fillaux for the Iatroscan measurements and Gustave Cauwet for the POC and PON data. This manuscript benefited from detailed comments by $\mathrm{S}$. Richardson, and we thank her. We are also grateful to anonymous reviewers and especially the one who took time to edit the manuscript. We thank the crew of RV 'Atalante' for their help during the cruise and IFREMER (Institut Français de Recherche pour l'Exploitation de la Mer) for logistic and financial support. The work was supported in part by the European Community Marine Science and Technology (MAST) Programme, under MAS2-CT920033.

\section{LITERATURE CITED}

Balkwill DL, Murphy EM, Fair DM, Ringelberg DB, White DC (1998) Microbial communities in high and low recharge environments: implications for microbial transport in the Vadose zone. Microb Ecol 35:156-171

Barnett PRO, Watson J, Connelly D (1984) A multiple corer for taking virtually undisturbed samples from shelf, bathyal and abyssal sediments. Oceanol Acta 7:399-408

Billett DMS, Lampitt RS, Rice AL, Mantoura RFC (1983) Seasonal sedimentation of phytodetritus to the deep-sea benthos. Nature 302:520-522

Carballeira NM, Shalabi, F, Stefanov K, Dimitrov K, Popov S, Kujumgiev A, Andreev S (1995) Comparison of the fatty acids of the tunicate Botryllus schlosseri from the Black Sea with two associated bacterial strains. Lipids 30:677-679

Carballeira NM, Sostre A, Stefanov K, Popov S, Kujumgiev A, Dimitrova-Konaklieva S, Tosteson CG, Tosteson TR (1997) The fatty acid composition of a Vibrio alginolyticus associated with the alga Cladophora coelothrix. Identification of the novel 9-methyl-10-hexadecenoic acid. Lipids 32: $1271-1275$

Cosson N, Sibuet M, Galeron J (1997) Community structure and spatial heterogeneity of the deep-sea macrofauna at three contrasting stations in the tropical northeast Atlantic. Deep-Sea Res I 44:247-269

DeLaca TE (1986) Determination of benthic rhizopod biomass using ATP analyses. J Foraminifer Res 16:285-292

Delong EF, Yayanos AA (1986) Biogeochemical function and ecological significance of novel bacterial lipids in deepsea procaryotes. Appl Environ Microbiol 51

Desvilettes C, Bourdier G, Amblard C, Barth B (1997) Use of fatty acids for the assessment of zooplankton grazing on bacteria, protozoans and microalgae. Freshw Biol 51: 730-737

Dunstan GA, Volkman JK, Barrett SM, LeRoi JM, Jeffrey SW (1994) Essential polyunsaturated fatty acids from 14 species of diatom (Bacillariophyceae). Phytochemistry 35: $155-161$

Gillan FT, Johns RB (1986) Chemical markers for marine bacteria: fatty acids and pigments. In: Johns RB (ed) Biological markers in the sedimentary environment. Elsevier, Amsterdam, p 291-309

Ginger ML, Santos V, Wolff GA (2000) A preliminary investigation of the lipids of abyssal holothurians from the northeast Atlantic Ocean. J Mar Biol Assoc UK 80:139-146

Gooday AJ (1984) Records of deep-sea rhizopod tests inhabited by metazoans in the North-East Atlantic. Sarsia 69: $45-53$

Gooday AJ (1991) Xenophyophores (Protista, Rhizopoda) in box-core samples from the abyssal northeast Atlantic Ocean (BIOTRANS area): Their taxonomy, morphology, and ecology. J Foraminifer Res 21:197-212 
Gooday AJ (1996) Xenophyophores (Protista), including two new species, from two abyssal sites in the northeast Atlantic Ocean. J Foraminifer Res 26:193-208

Gooday AJ, Tendal OS (1988) New xenophyophores (Protista) from the bathyal and abyssal northeast Atlantic Ocean. J Nat Hist 22:413-434

Gooday AJ, Bett BJ, Pratt DN (1993) Direct observation of episodic growth in an abyssal xenophyophore (Protista). Deep-Sea Res I 40:2131-2143

Gooday AJ, Pond DW, Bowser SS (2002) Ecology and nutrition of the large agglutinated foraminiferan Bathysiphon capillare in the bathyal NE Atlantic: distribution within the sediment profile and lipid biomarker composition. Mar Ecol Prog Ser 245:69-82

Guckert JB, Hood MA, White DC (1986) Phospholipid esterlinked fatty acid profile changes during nutrient deprivation of Vibrio cholerae: increases in the trans/cis ratio and proportions of cyclopropyl fatty acids. Appl Environ Microbiol 52:794-801

Harvey HR (1997) Catalysts or contributors? Tracking bacterial mediation of early diagenesis in the marine water column. Org Geochem 26:531-544

Harvey HR, Fallon RD, Patton JS (1986) The effect of organic matter and oxygen on the degradation of bacterial membrane lipids in marine sediments. Geochim Cosmochim Acta 50:795-804

Hessler RR, Jumars PA (1974) Abyssal community analysis from replicate box cores in the central North Pacific. Deep-Sea Res 21:185-209

Howell KL, Pond DW, Billett DSM, Tyler PA (2003) Feeding ecology of deep-sea seastars (Echinodermata: Asteroidea): a fatty acid biomarker approach. Mar Ecol Prog Ser 255:193-206

Jantzen E (1984) Analysis of cellular components in bacterial classification and diagnosis. In: Odham G, Larsson L, Mardh PA (eds) Gas chromatography/mass spectrometry-applications in microbiology. Plenum, New York, p 257-302

Kaneda T (1991) Iso- and anteiso-fatty acids in bacteria: biosynthesis, function, and taxonomic significance. Microbiol Rev 55:288-302

Lambert MA, Hickman-Brenner FW, Farmer III JJ, Moss W (1983) Differentiation of Vibrionaceae species by their cellular fatty acid composition. Int J Syst Bacteriol 33:777-792

Laureillard J, Pinturier L, Fillaux J, Saliot A (1997) Organic geochemistry of marine sediments of the SubAntarctic Indian Ocean sector: lipid classes-sources and fate. Deep-Sea Res II 44:1085-1108

Legeleux F, Reyss JL, Schmidt S (1994) Particle mixing rates in sediments of the North-East tropical Atlantic: evidence from ${ }^{210} \mathrm{~Pb}_{\mathrm{xs}},{ }^{137} \mathrm{Cs},{ }^{228} \mathrm{Th}_{\mathrm{xs}}$ and ${ }^{234} \mathrm{Th}_{\mathrm{xs}}$ downcore distributions. Earth Planet Sci Lett 128:545-562

Levin LA (1991) Interactions between metazoans and large, agglutinating protozoans: implications for the community structure of deep-sea benthos. Am Zool 31:886-900

Levin LA (1994) Paleoecology and ecology of xenophyophores. Palaios 9:32-41

Levin LA, Gooday AJ (1992) Possible roles for xenophyophores in deep-sea carbon cycling. In: Rowe GT, Pariente V (eds) Deep-sea food chains and the global carbon cycle. Kluwer Academic Publishers, Dordrecht, p 93-104

Levin LA, Thomas CL (1988) The ecology of xenophyophores (Protista) on Eastern Pacific seamounts. Deep-Sea Res 35: 2003-2027

Levin LA, DeMaster DJ, McCann LD, Thomas CL (1986) Effects of giant protozoans (class: Xenophyophorea) on deep-seamount benthos. Mar Ecol Prog Ser 29:99-104

Levin LA, Childers SE, Smith CR (1991a) Epibenthic, aggluti- nating foraminiferans in the Santa Catalina Basin and their response to disturbance. Deep-Sea Res 38:465-483

Levin LA, McCann LD, Thomas CT (1991b) The ecology of polychaetes on deep seamounts in the eastern Pacific Ocean. Ophelia Suppl 5:467-476

Levin LA, Blair NE, Martin CM, DeMaster DJ, Plaia G, Thomas CJ (1999) Macrofaunal processing of phytodetritus at two sites on the Carolina margin: in situ experiments using ${ }^{13} \mathrm{C}$-labeled diatoms. Mar Ecol Prog Ser 182:37-54

Méjanelle L, Laureillard J, Fillaux J, Saliot A, Lambert C (1995) Winter distribution of algal pigments in small- and large-size particles in the Northeastern Atlantic. DeepSea Res 42:117-133

Nichols PD, Volkman JK, Johns RB (1983) Sterols and fatty acids of the marine unicellular alga, FCRG 51. Phytochemistry 22:1447-1452

Pawlowski J, Holzmann M, Fahrni J, Richardson SL (2002). SSUrDNA analysis suggests that the xenophyophoran Syringammina corbicula represents a foraminiferan. FORAMS 2002, Perth

Perry GJ, Volkman JK, Johns RB, Bavor HJ (1979) Fatty acids of bacterial origin in contemporary marine sediments. Geochim Cosmochim Acta 43:1715-1725

Pinturier-Geiss L, Laureillard J, Riaux-Gobin C, Fillaux J, Saliot A (2001) Lipids and pigments in deep-sea sediments and interfacial particles from the Western Crozet Basin. Mar Chem 75:249-266

Pond DW, Gebruk A, Southward EC, Fallick AE, Bell MV, Sargent JR (2000) Unusual fatty acid composition of storage lipids in the bresilioid shrimp Rimicaris exoculata couples the photic zone with MAR hydrothermal vent sites. Mar Ecol Prog Ser 198:171-179

Pond DW, Allen CE, Bell MV, Van Dover CL, Fallick AE, Dixon DR, Sargent JR (2002) Origins of long-chain polyunsaturated fatty acids in the hydrothermal vent worms Ridgea piscesae and Protis hydrothermica. Mar Ecol Prog Ser 225:219-226

Rajendran N, Matsuda O, Imamura N, Urushigawa Y (1992) Variation in microbial biomass and community structure in sediments of eutrophic bays as determined by phospholipid ester-linked fatty acids. Appl Environ Microbiol 58: 562-571

Rajendran N, Matsuda O, Urushigawa Y, Simidu U (1994) Characterisation of microbial community structure in the surface sediment of Osaka Bay, Japan, by phospholipid ester-linked fatty acid analysis. Appl Environ Microbiol 60:248-257

Rajendran N, Matsuda O, Imamura N, Urushigawa Y (1995) Microbial community structure analysis of euxinic sediments using phospholipid ester-linked fatty acid biomarkers. J Oceanogr 51:21-38

Reinhardt SB, Van Vleet ES (1986) Lipid composition of twenty-two species of Antarctic midwater zooplankton and fish. Mar Biol 91:149-159

Relexans JC, Deming J, Dinet A, Gaillard JF, Sibuet M (1996) Sedimentary organic matter and micro-meiobenthos with relation to trophic conditions in the tropical northeast Atlantic. Deep Sea Res I 43:1343-1368

Richardson SL (2001) Syringammina corbicula sp. nov. (Xenophyophorea) from the Cape Verde Plateau, E. Atlantic. J Foraminifer Res 31:201-209

Riemann F, Tendal OS, Gingele FX (1993) Reticulammina antarctica nov. spec. (Xenophyophora, Protista) from the Weddell Sea, and aspects of the nutrition of xenophyophores. Polar Biol 13:543-547

Saliot A, Laureillard J, Peulvé S, Fillaux J (1997) Fatty acid signatures from bacteria at the freshwater/seawater 
boundary of the Krka estuary in winter, spring and autumn. Croat Chem Acta 70:323-332

Sibuet M (1991) EUMELI 2 Cruise Report. IFREMER, Brest

Sibuet M, Albert P, Charmasson S, Deming J and 19 others (1993) The benthic ecosystem in the three EUMELI sites in the Northeast tropical Atlantic: general perspectives and initial results on biological abundance and activities. Ann Inst Océanogr 69:21-33

Stein R (1991) Accumulation of organic carbon in marine sediments. In: Bhattacharji S, Friedman GM, Neugebauer HJ, Seilacher A (eds) Lecture notes in earth sciences. Springer-Verlag, Berlin, p 34

Tendal OS (1972) A monograph of the xenophyophoria (Rhizopodea, Protozoa). Galathea Rep 12:7-99

Tendal OS (1979) Aspects of the biology of Komokiacea and Xenophyophoria. Sarsia 64:13-17

Tendal OS (1994) Protozoa Xenophyophorea Granuloreticulosa: Psammina zonaria sp. nov. from the West Pacific and some aspects of the growth of xenophyophores. Mém Mus Nat Hist Nat 161:49-54

Tendal OS (1996) Synoptic checklist and bibliography of the Xenophyophorea (Protista), with a zoogeographic survey of the group. Galathea Rep 17:79-101

Tendal OS, Gooday AJ (1981) Xenophyophoria (Rhizopoda, Protozoa) in bottom photographs from the bathyal and abyssal NE Atlantic. Oceanol Acta 4:415-422

Tendal OS, Swinbanks DD, Shirayama Y (1982) A new infaunal xenophyophore (Xenophyophorea, Protozoa) with notes on its ecology and possible trace of fossil analogs.

Editorial responsibility: Otto Kinne (Editor), Oldendorf/Luhe
Oceanol Acta 5:325-330

Vangriesheim A, Pierre C, Laube E (1993) Hydrological conditions in the EUMELI area in the tropical Atlantic: water masses, variability of productivity/regeneration and of particle load. Ann Inst Océanogr 69:15-20

Vestal JR, White DC (1989) Lipid analysis in microbial ecology. Bioscience 39:535-541

Volkman JK (1986) A review of sterol markers for marine and terrigenous organic matter. Org Geochem 9:83-99

Volkman JK, Eglinton G, Corner EDS (1980a) Sterols and fatty acids of the marine diatom Biddulphia sinensis. Phytochemistry 19:1809-1813

Volkman JK, Johns RB, Gillan FT, Perry GJ (1980b) Microbial lipids of an intertidal sediment I. Fatty acids and hydrocarbons. Geochim Cosmochim Acta 44:1133-1143

Volkman JK, Kearney P, Jeffrey SW (1990) A new source of 4methyl sterols and $5 \alpha(\mathrm{H})$-stanols in sediments: prymnesiophyte microalgae of the genus Pavlova. Org Geochem 15: 489-497

Volkman JK, Barrett SM, Dunstan GA, Jeffrey SW (1993) Geochemical significance of the occurrence of dinosterol and other 4-methyl sterols in a marine diatom. Org Geochem 20:7-15

Volkman JK, Barrett SM, Blackburn SI, Mansour MP, Sikes EL, Gelin F (1998) Microalgal biomarkers: a review of recent research developments. Org Geochem 29:1163-1179

Zhukova NV, Kharlamenko VI (1999) Sources of essential fatty acids in the marine microbial loop. Aquat Microb Ecol 17:153-157

Submitted: March 18, 2003; Accepted: December 2, 2003 Proofs received from author(s): March 31, 2004 